\title{
Antecedent factors impacting country of origin (COO): an investigation into food provenance in China
}

by Walley, K., Cheng, L. and Liu, T.

Copyright, publisher and additional Information: This is the author accepted manuscript. The final published version (version of record) is available online via Transnational Press London

Please refer to any applicable terms of use of the publisher.

https://journals.tplondon.com/index.php/tmj/article/view/752

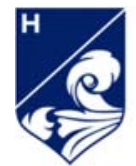




\title{
Antecedent Factors Impacting Country of Origin (COO): An Investigation into Food Provenance in China
}

\begin{abstract}
This paper reports a study that sought to investigate the antecedent factors influencing consumer $\mathrm{COO}$ perceptions. A review of the literature revealed that most previous studies consider these factors independently, however, it is now widely accepted that consumer decision making does not involve the consideration of variables one-at-a-time but rather as a small group of factors often referred to as the evoked set. This study, therefore, set out to fill a gap in the knowledge regarding the factors influencing consumer $\mathrm{COO}$ when considered collectively. A model of the antecedent factors impacting $\mathrm{COO}$ was developed from the literature and a three stage methodology involving both qualitative and quantitative techniques was then used to test the model. The findings not only confirm $\mathrm{COO}$ as an important factor in the decision making process of Chinese consumers when purchasing food products but go on to suggest that the role played by the antecedent factors of $\mathrm{COO}$ is much more complex than the existing literature might suggest. The main limitations of the study related to the work being conducted in just one country (China) and the inherent issues associated with research that is based on sampling. Despite the limitations, the paper makes an original contribution to knowledge regarding antecedent factors impacting $\mathrm{COO}$ and presents a number of implications for both practicing marketing managers and academic theorists.
\end{abstract}

Key words: Country of origin; COO; International marketing; Food provenance; China.

\section{$1.0 \underline{\text { Introduction }}$}

According to Tse and Gorn (1993, p57), Country-of-Origin (COO) may be defined as "the country where a product is produced", however, the concept is equally applicable to services (Guilhoto, 2018; Maurya and Gupta, 2015), brands (Arora et al, 2015; Johnson et al, 2016; Porto and Soyer, 2018), and online as well as offline purchases (Zhao et al, 2019). It is a key concept in marketing because it may have a significant impact on consumer behavior and decision making as, for instance, Priyadarsini and Goodwin (2009) note the pride with which some consumers speak about their Swiss watch, French wine or German car and conversely, their reluctance to acknowledge that their mobile phone was made in South Korea. Although most of the academic interest in $\mathrm{COO}$ relates to consumer decision making there is evidence (Dobrucali, 2019; Reichert and Altobelli, 2016; Schatzle and Jacob, 2019) to suggest that it also has an important role to play in industrial decision making.

$\mathrm{COO}$ has become increasingly important because of the advent of globalization and the concomitant growth in international trade (Han, 2010; Priyadarsini and Goodwin, 2009) that is causing products and services to be traded across national borders. Indeed, Lin and Chen (2006) posit that this phenomenon has been facilitated by the introduction of the General Agreement on Trade and Tariffs (GATT) in 1947 and then by the establishment of the World Trade Organisation (WTO) in 1995.

The increase in international trade means that there is a very real need for managers to understand consumers who live in different countries (Ahmed and d'Astous, 2008) and have different cultures than their own and so COO has become a key concept in international marketing (Andhn et al, 2016) and a very popular subject for research (Bloemer et al, 2009; Godey et al, 2012; Herz and Diamantopoulos, 2017; Phau and Suntornnond, 2006; Usunier, 2006). Despite its popularity, however, there are some aspects of the $\mathrm{COO}$ concept that are less well understood and it is one of these areas, the antecedent factors impacting $\mathrm{COO}$, that is the focus for this paper. Indeed, this paper will present the findings of a study that sought to fill a knowledge gap arising from much of the current knowledge having been generated by studying factors independently and the more realistic approach adopted in this paper which considers them collectively. To begin, however, it is useful to review the literature relating to $\mathrm{COO}$ generally and to antecedent factors specifically as this knowledge will be used to generate a model of the antecedent factors impacting $\mathrm{COO}$ which will then be validated through the collection of primary data. 


\subsection{Theoretical Background}

The inception of the COO concept is often attributed to Dichter (1962) and his acknowledgement of the significance that 'made-in' labels may have on the acceptance and success of products while the earliest research on COO was undertaken by Schooler (1965) when he published what Pharr (2005) describes as a seminal paper on $\mathrm{COO}$ which showed that consumers purchase decisions may be impacted by national origin.

COO research was initially undertaken in developed countries (Hamin and Elliot, 2006) as companies that originated in developed countries looked to take advantage of the lower costs associated with manufacturing in less developed countries. However, researchers quickly realized that many less developed countries actually had emerging economies that also constituted viable markets for their products and services but that also required knowledge and understanding of $\mathrm{COO}$ amongst those consumers and so $\mathrm{COO}$ research subsequently took place in those countries too (eg Agbonifoh and Elimimian, 1999).

While $\mathrm{COO}$ is a popular focus for research the phenomenon is not completely pervasive and some researchers (eg Ettenson et al, 1988; Liefeld, 1993, 2004; Lim and Darley, 1997; Lim et al, 1994) have failed to find a statistically significant relationship between $\mathrm{COO}$ and consumer choice. Indeed, Balabanis and Diamantopoulos (2008 and 2011), Liefeld (2004), and Samiee et al (2005) have shown that consumers brand origin knowledge is remarkably poor and often they do not know the real COO of even well-known brands. This has led Magnusson et al $(2011, \mathrm{p} 455)$ to propose that an alternative stream of research has emerged (eg Balabanis and Diamantopoulos, 2008; Liefeld 2004; Samiee et al, 2005 ) that "...suggests that most consumers care very little about the origin of products" which has then caused some (eg Samiee, 2010; Usunier, 2006; Usunier and Cestre, 2007) to question whether COO is still relevant.

The fact that some studies find a statistically significant relationship between $\mathrm{COO}$ and consumer choice while others don't appears to be due to a number of factors. In the first instance, Ahmed and d'Astous (2001), Liefeld (1993) and Zhang (1996) argue that product type impacts the level of importance that consumers attach to $\mathrm{COO}$. So for instance, when products are complex (eg houses, cars, home theatre systems) or have additional social dimensions (eg luxury items) and purchase requires a high level of involvement then consumers are more likely to incorporate $\mathrm{COO}$ in their deliberations (see Ahmed and d'Astous, 1993, 2001; Liefeld, 1993; Okechuku and Onyemah, 1966; and Piron, 2000). As such, COO effects are seen as context specific (Kim and Park, 2017) which has led authorities such as Verlegh and Steenkamp (1999) and Veale and Quester (2009) to note that it is quite possible that while some source countries do impact consumer behavior and consumer purchase decisions for some products for others they do not and so contradictory results are valid.

A second factor is that in some cases consumers relate products and services to countries not by virtue of $\mathrm{COO}$ but by some related concept such as Country of Manufacture (Arora et al, 2015; Johnson et al, 2016; Saeed, 1994), Country of Assembly (Al-Aali et al, 2015; Saeed, 1994), Country of Design (Genc and Wang, 2017; Wu and Dodool, 2016;), Country of Parts (Al-Aali et al, 2015), Country of Ingredients Authenticity (Cheah et al, 2016), country in which corporate headquarters of the company making the brand is located (Krupka et al, 2014) or country with which a manufacturer's products or brand name is associated (Lin and Chen, 2006). In some instances this phenomenon may be exacerbated by the concept of multiple sourcing or what Pham (2006) calls hybrid products that have affiliations with several countries.

A third factor is that in some instances the $\mathrm{COO}$ effect may be subsumed within, or neutralized by, other variables and may not be readily visible to researchers. These other variables may include country image (Agarwal and Sikri, 1996; Godey et al, 2012; Han and Terpstra, 1988; Laroche et al, 2005; Lin and Chen, 2006; Nagashama, 1970 and 1977; Pharr, 2005; Usunier, 1993 and 2006) or a variation such as ecological country image (Dekhili and Achabou, 2015), brand name (Krupka et al, 2014), brand identity (Pharr, 2005) or brand image (Kim et al, 2015) and the phenomenon is particularly relevant for global brands that are able to command a price premium that outweighs COO (Winit et al, 2014).

Finally, some researchers (Agarwal and Kamakura, 1999; Peterson and Jolibert, 1995; Verlegh and Steenkamp, 1999) postulate that the strength of the relationship between $\mathrm{COO}$ and consumer choice is a product of the methodology used to undertake the research. While studies that focus on COO 
separately tend to find a strong relationship between $\mathrm{COO}$ and consumer choice, studies that incorporate several variables in addition to $\mathrm{COO}$ have found a much weaker relationship. It would appear, therefore, that where other information is absent consumers will use COO to assist in evaluating products and services but that where other indicators of quality and reliability are present (eg brand image) then they often take precedence over COO.

Although the strength of the $\mathrm{COO}$ effect and indeed the validity of the concept itself has been questioned commentator's such as Magnusson et al (2011) and Pharr (2005) conclude that as the majority of studies have confirmed a link between $\mathrm{COO}$ and consumer choice (eg Dobrenova et al, 2015; Holdershaw and Konopka, 2018; Hussein and Fraser, 2018; Insch and Cuthbert, 2018, Kim et al, 2015; Nagy, 2019; Otter et al, 2018; Tiwari, 2016; Visbal et al, 2017) then COO does affect many product evaluations and so it would seem logical to assume that in most instances it does remain a valid concept to research.

COO research is often implemented within what Bilkey and Nes (1982) and Bloemer et al (2009) refer to as the cognitive approach to consumer behaviour. In this approach the product is viewed as a series of attributes (Krupka et al, 2014) or cues (Joji and Ajin, 2015; Keller, 2003; Liefeld, 1993; Magnusson et al, 2011; Phau and Suntornnond, 2006; Piron, 2000; Tiwari, 2016) that can either encourage product acceptance or act as a barrier (Phau and Suntornnond, 2006). These cues may relate directly to the physical product itself, for instance, colour, weight, size, taste, or physical performance, and be known as intrinsic cues, or they may be related to the product but not directly, for instance brand name, image, reputation, and price, in which case they are known as extrinsic cues (Liefeld, 1993). Because COO is related to the product but not directly it is an extrinsic cue.

Where consumers are not familiar with a product it can be difficult for them to acquire information relating to intrinsic cues which means that they fall back on extrinsic cues when evaluating products (Bredahl, 2004; Magnusson et al, 2011) because they are seen as valid indicators of product quality and value (Dodds, 1991; Kardes et al, 2004; Magnusson et al, 2011). As such, extrinsic cues like COO may serve as cognitive short-cuts for situations where information regarding intrinsic cues is perceived as deficient (Bredahl, 2004; Chaiken, 1987; Keller, 2003; Magnusson et al, 2011). Further, where information regarding $\mathrm{COO}$ is either lacking or confused then consumers may fall-back further and use generic factors, such as country image (Agarwal and Sikri, 1996; d'Astous and Ahmed, 1999; Erickson et al, 1984; Han, 1989; Laroche et al, 2005; Lee and Ganesh, 1999; Roth and Romeo, 1992; Samiee, 2010), for origin information to help them make product evaluations. Indeed, this process may be thoughtless and automatic (Magnusson et al, 2011) with the consumer unaware of the process (Greenwald and Banaji, 1995) which is based on internally stored and subconscious schemas (Shimp et al, 1993).

One schema relating to $\mathrm{COO}$ is based on stereotyping which is a "...psychological process that is commonly used to explain how consumers react to COO information (Ahmed and d'Astous, 2008, p78). Stereotypes of countries can take the form of either a multivariate summary construct or a simple halo (Han, 1989), be explicit or implicit (Diamantopoulos et al, 2017), and be positive or negative but whatever their nature they are used by consumers to assist in the evaluation of products (Fischer and Zeugner-Roth, 2017; Johansson and Thorelli, 1985; Lin and Chen, 2006; Magnusson et al, 2011; Roth and Romeo, 1992) and an understanding of such stereotypes is essential in developing international marketing strategies. Indeed, research has found that because of an association with technological development (Ahmed and d'Astous, 2001; Chinen et al, 2000; Hsieh, 2004; Huddlestone et al, 2001; and Wang and Lamb, 1983) which is then related to superior quality and performance (Priyadarsini and Goodwin, 2009), and / or cultural appropriation (Suh et al, 2016) consumers demonstrate a pervasive preference for products originating from developed countries. Enduring favourable stereotypes such as this may be viewed as a halo effect for products originating from developed countries (Erickson et al, 1984; Johansson et al, 1985; Lin and Chen, 2006).

Another schema relating to $\mathrm{COO}$ is based on ethnocentricity which is a term that was first used by Ludwig Gumplowicz (Bizumic, 2014) and refers to the act of judging another culture based on preconceptions that are found in the values and standards of one's own culture (Omohundro, 2008). In the context of marketing the concept is often refined so as to focus on Consumer Ethnocentrism which may be defined as the way that consumers consider products originating from their own country as being superior to products made in other countries (Shimp and Sharma, 1987). At the individual consumer level ethnocentrism is based on factors such as culture, nationalism, patriotism, 
internationalism, demography, economic conditions, and personal characteristics (Balabanis et al, 2001; Maier and Wilken, 2017; Sharma et al, 1995).

Pharr (2005) and Walley et al (2014) postulate that much COO research is based on a simple conceptual model involving antecedents, moderators and outcomes. Pharr (2005) defines antecedents as being "...the precursors to or determinants of a construct" while moderators are factors that serve to reduce the impact of an effect and outcomes are a product of the antecedents and moderators. This model is presented as Table 1 along with the underpinning variables identified in the literature. Indeed, as it has become more apparent that $\mathrm{COO}$ is a multidimensional concept that plays a role in both product assessment and the decision making process (Bilkey and Nes, 1982; Jaffe and Martinez 1995; LaTour and Henthorne, 1990; Priyadarsini and Goodwin, 2009; Reierson, 1966; Solomon, 2015; Verlegh and Steenkamp, 1999; and Zain and Yasin, 1997) and that "...COO affects different aspects of consumer evaluation and choice behaviour" (Ahmed and d'Astous, 2008, p78) then the list of output variables in the $\mathrm{COO}$ model has grown.

While this model is a useful means of identifying factors impacting $\mathrm{COO}$, the factors themselves have in the main been investigated using a quasi-experimental deductive approach that focuses on the variables individually. The findings of these types of study are generally reliable but validity is often difficult to establish which Andehn and L'espoir Decosta (2018) claim is an issue with many COO studies. As a consequence, the model itself is largely hypothetical and little, if anything, is known about the factors collectively (Ahmed and d'Astous, 2008). In order to address this knowledge gap the remainder of this paper will report the findings of a study that adopted an inductive approach to collectively research the factors impacting $\mathrm{COO}$ and the relationships between them in the context of a $\mathrm{COO}$ study of food provenance in China with a view to producing results that are both reliable and valid.

Table 1 - Conceptual Model of COO

\begin{tabular}{|l|l|l|}
\hline \multicolumn{1}{|c|}{ Antecedents } & \multicolumn{1}{|c|}{ Moderators } & \multicolumn{1}{c|}{ Outcomes } \\
\hline Demographic variables & Context & Product quality \\
Social class, & Consumers' education & Brand quality \\
Travel abroad, & Consumers product knowledge & Product attributes \\
Education & Product expertise & Consumer attitudes \\
Motivation & Product familiarity & Purchase intentions \\
Ability to process information & Brand familiarity & Consumer preference \\
Ethnocentrism & Product origin congruency & Purchase intentions \\
Animosity to other ethnic & Product origin typicality & Purchase value \\
groups & Product type & Purchase evaluation \\
Cultural orientation & Category level & Brand image \\
Materialism & Trust & \\
Value consciousness & Perceived risk & \\
& & \\
\hline
\end{tabular}

Developed from: Ahmed et al, 2002a \& b; Ahmed and d'Astous, 1996 and 2008; Balabanis and Diamantopoulos, 2004; Balabanis et al, 2002; Balestrini and Gamble, 2006; Beverland and Lindgreen, 2002; Biswas et al, 2011; Chattalas and Takada, 2013; Chiou, 2003; d'Astous and Ahmed, 1999; Ferguson et al, 2008; Gurhan-Canli and Maheswaran, 2000; Han, 2010; Hanzaee, 2008; Hamin and Elliott, 2006; Hamzaoui-Essoussi et al, 2011; Hsieh, et al, 2004; Insch, 2003; Jian and Guoqun, 2007; Jiménez and Martin, 2012 \& 2014; Johansson, 1989; Josiassen et al, 2008; Josiassen and Assaf, 2010; Kabadayi and Lerman, 2011; Kaynak et al, 2000; Kim and Pysarchik, 2000; Kim, 2006; Knight and Calantone, 2000; Koschate-Fischer et al, 2012; Koubaa, 2008; Kucukemiroglu et al, 2005; Lee and Ganesh, 1999; Leonidou et al 1999; Liefeld et al, 1996; Lim et al, 2014; Lin and Chen, 2006; Martin and Cervino, 2011; Michaelis et al, 2008; Paswan and Sharma, 2004; Peterson and Jolibert, 1995; Phau and Suntornnond, 2006; Prendergast et al, 2010; Richardson Jr, 2012; Sharma, 2011; Tigli et al, 2010; Tseng and Balabanis, 2011; Wall et al, 1991; Wong et al, 2008; Xu et al, 2013; Zolfagharian and Sun, 2010; Zolfagharian et al, 2014.

\subsection{Methodology}

This study was carried-out in three stages with Stages One and Two being conducted as part of a food provenance or "place of origin" (Oxford University Press, 2019) project in China and Stage 3 being conducted for the specific purpose of investigating the antecedent factors impacting COO. 
consumers who were resident in the Beijing municipal area and had been chosen using judgment sampling to ensure a representative sample of the broader Chinese population in terms of age and gender. These focus groups simply sought information about the purchase process and the factors, particularly $\mathrm{COO}$, impacting purchase decisions relating to selected food and drink products.

Stage Two was quantitative in nature and took the form of a street survey. A total of 198 questionnaires were completed by an equal number of participants in street intercept interviews at shopping malls in four locations approximately $5 \mathrm{~km}$ from Beijing city centre. The participants were selected using a systematic random sampling technique whereby the interviewers approached every tenth person. In the event $51 \%$ of the selected sample were male, and the modal age of the respondents was $18-25$. In order to address the issue of experimental isolation of the COO factor inflating its importance (eg Balabanis and Diamantopoulos, 2008; Magnusson et al, 2011; Samiee et al, 2005; Usunier, 2006) the survey adopted a conservative approach and considered COO relative to other attributes impacting the purchase decision that had been identified in Stage One. This stage of the study generated the data relating to the preferred $\mathrm{COO}$ for selected food and drink products that are shown in Table 2.

Stage Three was, again, qualitative in nature and took the form of another focus group discussion involving 10 Chinese students studying in the UK. The aim of this group discussion was to investigate the antecedent factors impacting $\mathrm{COO}$ and this was achieved by using the data from the Stage 2 survey as a prompt, presenting it to the Stage 3 participants on a product-by-product basis, and asking why the $\mathrm{COO}$ data had been rated in the way that it had. The focus group discussions followed common practice (Silverman, 2015) and were recorded, transcribed and the data subject to thematic analysis. 
Table 2: Preferred Country-Of-Origin

\begin{tabular}{|c|c|}
\hline & Mean \\
\hline \multicolumn{2}{|c|}{ Preferred country-of-origin of chocolate: } \\
\hline 1. Switzerland $(n=155)$ & 3.9613 \\
\hline 2. Belgium $(n=167)$ & 3.8824 \\
\hline 3. Italy $(n=141)$ & 3.6809 \\
\hline 4. America $(n=133)$ & 3.5188 \\
\hline 5. Japan $(n=135)$ & 3.4220 \\
\hline 6. China $(n=167)$ & 3.3293 \\
\hline \multicolumn{2}{|c|}{ Preferred country-of-origin of salmon: } \\
\hline 4. Japan $(n=136)$ & 3.8824 \\
\hline 2. Norway $(n=115)$ & 3.8696 \\
\hline 3. Canada $(n=99)$ & 3.4646 \\
\hline 1. Russia $(n=78)$ & 3.2436 \\
\hline 5. China $(n=123)$ & 2.9837 \\
\hline \multicolumn{2}{|c|}{ Preferred country-of-origin of baby milk powder: } \\
\hline 5. New Zealand $(n=112)$ & 3.9018 \\
\hline 4. Netherlands $(n=102)$ & 3.8627 \\
\hline 3. Germany $(n=84)$ & 3.6310 \\
\hline 1. Switzerland $(n=80)$ & 3.5625 \\
\hline 2. United Kingdom $(n=76)$ & 3.4079 \\
\hline 6. China $(n=121)$ & 2.8182 \\
\hline \multicolumn{2}{|c|}{ Preferred country-of-origin of beer: } \\
\hline 2. Germany $(n=146)$ & 4.0342 \\
\hline 5. China $(n=173)$ & 3.8266 \\
\hline 1. United Kingdom $(n=98)$ & 3.4898 \\
\hline 4. Mexico $(n=91)$ & 3.4176 \\
\hline 3. France $(n=85)$ & 3.2588 \\
\hline \multicolumn{2}{|c|}{ Preferred country-of-origin of steak: } \\
\hline 3. Australia $(n=140)$ & 4.0571 \\
\hline 2. America $(n=132)$ & 3.9470 \\
\hline 1. United Kingdom $(n=120)$ & 3.7583 \\
\hline 4. China $(n=160)$ & 3.3375 \\
\hline \multicolumn{2}{|c|}{ Preferred country-of-origin of wine: } \\
\hline 7. France $(n=133)$ & 4.0902 \\
\hline 6. Australia $(n=104)$ & 3.7212 \\
\hline 1. Chile $(n=86)$ & 3.6977 \\
\hline 8. Italy $(n=110)$ & 3.6455 \\
\hline 2. America $(n=102)$ & 3.3922 \\
\hline 5. Spain $(n=100)$ & 3.3800 \\
\hline 4. Argentina $(n=83)$ & 3.3253 \\
\hline 9. China $(n=158)$ & 3.3165 \\
\hline 3. South Africa $(n=78)$ & 3.2692 \\
\hline
\end{tabular}

Key: 1 = Strongly Dislike, 2 = Slightly Dislike, 3 = Neither like nor dislike, 4 = Slightly like, 5 = Strongly like, 6 = Don't know. 


\subsection{Results}

The antecedent factors impacting $\mathrm{COO}$ in the decision making process regarding the food products researched in Stage 3 of this study are identified in Table 3. Despite the best efforts of the Moderator the discussions relating to the different food groups were not the same. Participants talked more freely about the factors impacting $\mathrm{COO}$ in respect of some products rather than others, possibly an indication of the level of involvement associated with the purchase decisions, but obviously this resulted in more factors being identified for some food products rather than others. However, this was not considered an issue because, being qualitative in nature, the research was simply seeking insight and it did not matter that there was an imbalance in the discussion between the food products. Further, it should be noted that in some instances there was a significant association between factors and the decision to identify them separately and list them with certain food products in Table 2 was somewhat judgmental but facilitates subsequent consideration later in this paper.

Table 3: Antecedent factors influencing COO

\begin{tabular}{|c|c|c|c|c|c|}
\hline Chocolate & Salmon & $\begin{array}{c}\text { Baby Milk } \\
\text { Powder }\end{array}$ & Beer & Steak & Wine \\
\hline $\begin{array}{l}\text { Quality (scandal) } \\
\text { Price } \\
\text { Reputation } \\
\text { History \& heritage } \\
\text { Ethnocentricity } \\
\text { Culture } \\
\text { Habit }\end{array}$ & Availability & $\begin{array}{l}\text { Quality (scandal) } \\
\text { Price } \\
\text { Reputation } \\
\text { Advertising } \\
\text { National image } \\
\text { Ethnocentricity }\end{array}$ & $\begin{array}{l}\text { Quality (safety) } \\
\text { Price } \\
\text { Reputation (branding) } \\
\text { Availability (alternative } \\
\text { products \& protected } \\
\text { status) } \\
\text { History \& heritage } \\
\text { Culture (social cache) } \\
\text { Product range } \\
\text { Fashion } \\
\end{array}$ & $\begin{array}{l}\text { Quality } \\
\text { Price (value) }\end{array}$ & $\begin{array}{l}\text { Quality (history, } \\
\text { heritage \& tradition) } \\
\text { Price } \\
\text { Reputation } \\
\text { Product availability } \\
\text { Culture }\end{array}$ \\
\hline
\end{tabular}

The participants referred to quality as a factor influencing $\mathrm{COO}$ evaluation in the context of most of the food products studied, however, quality is a multi-dimensional concept and this characteristic was clear to see here as different aspects of quality were the focus of discussion regarding the different food products. In the context of most food products the discussion started by reference to a desire for premium quality but the discussion relating to beer made an association with product safety; the discussion about wine related quality to the history, heritage and tradition associated with wine production in France but not South Africa; and the discussions about baby milk powder and chocolate led participants to talk about relatively recent food scandals that led to catastrophic failings in product quality.

A second factor mentioned by the participants as influencing $\mathrm{COO}$ evaluation in the context of most of the food products studied was price but, again, the discussions in the context of the selected foods served to highlight the multivariate nature of this factor. In the context of wine and chocolate it appeared that the participants expected to pay a premium price for a premium quality product while in the context of steak they talked about best value and in respect of beer the price was evaluated relatively against the price of wine. Of most interest, however, was the discussion regarding baby milk powder where the participants expressed a willingness to pay a premium price for high quality products that originated overseas, presumably because they were considered safer than products produced in China, but then went on to note the low price of products originating from New Zealand. This may at first appear an anomaly with New Zealand firms failing to fully capitalise on an apparent marketing asset but, if the participants observations are accurate, with New Zealand firms being implicated in some of the scandals surrounding baby milk powder in China it could also be a deliberate marketing strategy on the part of the New Zealand firms to buy back lost market share.

The participants mentioned reputation as a factor influencing $\mathrm{COO}$ evaluation in the context of chocolate, baby milk powder, beer and wine purchases and, again, it impacted purchase decisions in different ways. Although reputation appeared but as a mention with regard to chocolate purchases and only in the context of well-known German beer festivals with regard to beer it had a much more complicated impact with regard to baby milk powder and wine. In the context of baby milk powder the participants felt that reputation was built upon advertising that in respect of products originating from New Zealand was based upon a country image that portrayed an image of fertile grasslands, superior 
standards of animal husbandry, low carbon emissions, and environmentally friendly products. The discussion regarding baby milk powder also revealed that the participants did not associate the product with countries like the Netherlands because they felt that the product was incongruent with the national image. Similarly, while the participants appeared perfectly happy with wine originating from France (they believed that the climate was particularly well suited to producing wine) they felt that wine was incongruent with their perceived image of South Africa which, rightly or wrongly, they associated with chemical production.

Product availability was another factor influencing $\mathrm{COO}$ evaluation that was mentioned by the participants in the context of salmon, beer and wine purchases. The participants felt that wine from different countries was supplied into different Chinese cities, possibly relating to historical ties with those countries, while salmon was associated with Japan because it was frequently on the menu in Japanese sushi restaurants that Chinese consumers favoured. Similarly, German beer was favoured by the participants primarily because of it being available in the German restaurants that are popular in China but the consumers preference for German beer may also be due to the fact that the participants only recognized one Chinese beer of comparable quality. The discussion regarding beer did, however, suggest that in some regions Chinese beer is more popular because it has a protected status which means that beer from overseas is simply not available.

History and heritage have already been acknowledged as a factor influencing the $\mathrm{COO}$ evaluations of the participants regarding wine but it was also mentioned in the context of chocolate and beer. Indeed, the participants felt that Chinese consumers often associated chocolate with Switzerland and beer was often associated with Germany because both countries have a long history and heritage of producing these products.

Ethnocentricity is regarded as a common factor influencing $\mathrm{COO}$ evaluations but in this study, while the participants did make reference to it, it wasn't in the normal manner. In this study the participants touched on ethnocentrism with regard to baby milk powder and chocolate but, because baby milk powder and chocolate originating from China have been the subject of food scandals, the participants favoured products originating from abroad which seems to be a case of reverse-ethnocentricity.

Culture is another factor that might be expected to impact $\mathrm{COO}$ evaluations but which in reality may do so in a variety of ways. In this study the participants mentioned culture in the context of purchasing chocolate, beer and wine, and in all three cases the discussions revealed various aspects to the subject. In the case of chocolate the discussion suggested that Chinese consumers find the idea of Chinese chocolate incongruent with national identity because they hold expectations that non-traditional foods (like chocolate) should originate outside of China. The participants did, however, feel that Chinese culture was changing and that a developing trend to gift and drink beer on social and business occasions was causing Chinese consumers to favour German beers which provided greatest social cache as drinkers tended to show-off their German beer on social media which suggests that purchase is imbued with an element of conspicuous consumption. Indeed, the conspicuous consumption theme extended into the discussion concerning wine where it was considered in the context of gifting. In China a particularly important aspect of Chinese culture is "guanxi" which, interpreted literally, refers to "social network" (Jap, 2010) and a key aspect of this is gift-giving. As with cultures across the world, the rules of guanxi are tacit and somewhat flexible but known and understood by the majority and it is important to ensure that gifts are of the right pecuniary value to match the recipients social standing and put the giver in the correct light to gain face, however, the participants felt that wines originating from China were often low priced and poorly packaged which meant that they were not suitable for gifting in the Chinese cultural context.

Product range, fashion, and habit were the final three factors identified by the participants. While the former two were mentioned in the context of beer and the discussion was brief and limited it is worth considering habit in a little more detail as while mention of this factor was also brief it may well have an impact, albeit not recognized, in the purchase of all the other products tested and beyond. The impact of habit is not always acknowledged but some $45 \%$ of human behavior is repetitive (Wood et al, 2002) and a significant amount of consumer behavior and decision making is similarly habitual (Seetharaman, 2004) and so, with respect to this study, once patterns of behavior with regard to COO have been established and they become habitual it is quite conceivable that the factors outlined above will continue to play an important role in the decision making process for food products into the future and it is important to recognize this phenomenon. 


\subsection{Discussion}

It was clear that the participant's views and beliefs about factors were not necessarily based on facts but are perceptual in nature. Indeed, congruent with the views of Balabanis and Diamantopoulos (2008), in some instances the participant's beliefs were based on a tremendous amount of ignorance about both the countries products originated from and the countries themselves. In fact, and as predicted by Bredahl (2004) and Magnusson et al (2011), where the participants did not have facts on which to base their views and beliefs then they fell back on extrinsic cues and associations often served to fill the knowledge gap. A common and hence potentially particularly important association was that between $\mathrm{COO}$ and country image.

While the use of country image associations in consumer decision making is well documented in the literature (Agarwal and Sikri, 1996; d'Astous and Ahmed, 1999; Erickson et al, 1984; Han, 1989; Laroche et al, 2005; Lee and Ganesh, 1999; Roth and Romeo, 1992; Samiee, 2010) what is not covered so well but which was clearly apparent in this study was the impact of both negative country image and incongruent national image. So for instance, the participants did not like the idea of baby milk powder originating from China because of the scandal surrounding melamine contamination of baby milk powder made in China and they did not like the idea of baby milk powder originating from the Netherlands because they simply did not associate baby milk powder production with this country.

Similarly, while ethnocentricity is also a well-documented concept in the literature (Balabanis et al, 2001; Bizumic, 2014; Omohundro, 2008; Sharma et al, 1995; Shimp and Sharma, 1987) what receives less attention but which was also apparent in this study was reverse-ethnocentricity. Normally, ethnocentricity is associated with a tendency to favour products originating from one's own country of origin but this study highlighted the potential for reverse ethnocentricity as the Chinese participants were, to varying extents, biased against many of the food products originating from China. While there was something of a low level bias against Chinese food products based on perceptions of them having inferior quality levels when compared to products originating from overseas in the case of baby milk powder they were strongly biased against products originating from China for the very specific reason of the melamine contamination scandal.

Culture is yet another subject that has received a lot of attention in the academic literature (eg Hofstede, 2001; Steenkamp, 2019; Usunier, 1993) but this study also served to reinforce Gurhan-Canli and Maheswaran's (2000) view that buying factors, including COO, may be perceived differently in different contexts. In this study conducted in the Chinese context it was clear that culture, and especially the role played by guanxi and face, influenced participant's views about $\mathrm{COO}$ when evaluating products to give as gifts. Specifically, and as predicted by Jap (2010) and Zhang (1996), the participant's would not wish to give products that were low priced and poorly packaged and so this may well lead them to purchase products originating from countries that they perceived to offer the desired standard of quality and price.

The aforementioned findings do provide insight into $\mathrm{COO}$ as a factor influencing consumers purchase decisions but it is possible to make some further conjectures by considering the findings at a higher level of abstraction. For instance, it is apparent that in most of the instances considered as part of this study $\mathrm{COO}$ influences consumer decision making by contributing to an aggregate compensatory evaluation of a product within the decision making process. However, in some instances, COO may serve to exclude a particular product from the consumer's decision making process and so serves as a non-compensatory decision factor. In these cases, $\mathrm{COO}$ is not just a factor in the decision but the one and only factor in the decision and so is not just very important but is actually the essential determinant of that decision.

Considering the findings as a whole it is also apparent that it is difficult to fully understand the role of some factors as they may be both antecedents and moderators depending on circumstance. It is also apparent that many of the seemingly individual factors influencing $\mathrm{COO}$ are not actually unrelated because there is significant overlap and in some cases a factor is based on one or more other factors. The tendency to assume that the factors are independent may well be derived from the common practice of listing factors which may assist in identifying individual influencing factors but does not present an accurate indication of the relationships between the factors. This then suggests that the original antecedents-moderators-outcomes model shown in Table 1, while intuitively appealing, is rather 
simplistic in terms of explaining the impact that $\mathrm{COO}$ has on actual consumer behaviour.

\subsection{Practical and Theoretical Implications}

The study on which this paper is based has a number of practical as well as theoretical implications. Indeed, at the practical level, as well as providing valuable up-to-date market research suggesting a significant opportunity for foreign companies wishing to enter or operate in the Chinese market, the data also provides valuable insight into the markets of the food products that were the focus for this study which might allow companies to develop more effective marketing and promotional strategies.

Variables such as product quality and reputation are multivariate and not particularly useful from the management perspective (Insch et al, 2016; Rashid et al, 2016). Also, it is readily apparent that the manner in which participants use factors is often situation-specific which renders their use in the decision making process complex. It would appear apposite, therefore, to suggest that there is a need to conduct market research on any and all products that a manager is contemplating introducing into a foreign market.

Another key point for a marketing manager concerns product availability and the importance of securing appropriate distribution outlets. If products are not on the shelves the consumers cannot buy them and, therefore, rather than being based on experience, their perceptions of the products and their $\mathrm{COO}$ are based on generic reputation and especially of the associated country image. Indeed, where management is considering entering a new market, especially where consumers have little prior knowledge of the product, they should assume that their product will be evaluated by the consumers on a range of factors including the image of the country from where they originate and manage the products accordingly.

In respect of some products, history and heritage are essential for establishing a congruent and compelling $\mathrm{COO}$ and yet they are very difficult to copy which means that they are, in effect, the basis of a sustainable competitive advantage. One example of such a product is champagne where consumers expect the product to have a rich history and heritage that is almost unique, not least because within the EU the product has Protected Designation of Origin status. In situations like this a marketing manager must imbue his or her product with history and heritage by either producing in the champagne region of France or at least producing a similar product (eg Proseco) in France so that the product may take advantage of an association with the country of France.

In most instances ethnocentricity means locating production in the domestic country but this may not be necessary in the Chinese context as the participants in this study demonstrated reverseethnocentricity with regard to certain food products, where they preferred products made abroad. While the effect appeared to be product-specific managers should be aware that for some food products this appears to represent a good opportunity to export into China. Conversely, however, with regard to other food products the participants also demonstrated an aversion to food products originating from certain foreign countries and in these instances managers would be advised to follow the advice to be found in the literature (eg Aichner et al, 2017; Hamin and Elliot, 2006; Jimenez and Martin, 2012; Kim, 2006; Rashid, 2017; Richardson Jr, 2012, and Smaoui et al, 2016) and either produce the product elsewhere or obfuscate regarding the products origins.

Economic development has proceeded at a very fast rate in China and the Chinese economy is now the second largest in the world (World Bank, 2017). This economic growth may well be leading to changes in society and this study certainly found evidence that Chinese culture is changing. These changes in culture are then leading to changes in consumer behavior which would seem to offer some products originating from outside China good opportunities. Indeed, the Chinese cultural phenomena of guanxi and face are particularly important in that they encourage the practice of gift-giving. However, these cultural concepts also require that gifts should be of an appropriate status which, again, creates a very good opportunity for products originating outside of China.

At the theoretical level, academic researchers should note that a comparison of the antecedent factors recognized in previous studies and summarized in Table 1 and the antecedent factors identified in this study and shown in Table 3 reveals that while there are some similarities (eg ethnocentrism, culture, and value) there are also numerous differences. Many of the recognized antecedent factors in Table 1 
are, in fact, generic background characteristics of the respondents (eg demographic variables, social class, education, and motivation) while the antecedent factors in Table 3 are largely attributes of the product or service encounter itself. This is probably a facet of the research approach used in previous studies (ie deductive) being different to that used in this study (ie inductive) but does suggest that antecedents may be considered as background or foreground factors and it may be useful to make this distinction as while both are useful in explaining $\mathrm{COO}$ the background factors are largely a given while the foreground factors are more likely to be manageable.

\section{$7.0 \underline{\text { Conclusion }}$}

Previous research on antecedent factors influencing consumer behaviour has tended to be deductive and focused on one or a small number of variables. The aim of this study was to investigate the factors influencing consumer $\mathrm{COO}$ perceptions collectively as a self-determined decision set and it did so via a methodology that employed both qualitative and quantitative techniques in a three stage process. Despite limitations relating to the work being conducted in China which is an emerging economy with a unique culture, the fieldwork being conducted in Beijing which may not be representative of the Chinese market as a whole, and the inherent issues associated with research that is based on sampling and qualitative research that make use of very small sample sizes, the study makes an original contribution to knowledge by providing valuable additional insight into the antecedent factors influencing consumer COO perceptions.

In the first instance, the study confirms that Chinese consumers can and do differentiate between food products on the basis of national origin which means that the findings contribute to the body of evidence that supports the existence of a $\mathrm{COO}$ effect. The study then goes on to identify the factors that impact consumers decision making regarding $\mathrm{COO}$ as well as investigating the relationships between these factors. It is readily apparent that while in most situations the factors render $\mathrm{COO}$ as a factor in a compensatory decision there are instances where $\mathrm{COO}$ is the sole or key determinant in a noncompensatory decision. It is, therefore, also apparent that the simple antecedents-moderatorsoutcomes model used to underpin much of the existing research on $\mathrm{COO}$ is rather simplistic when it comes to explaining the role of $\mathrm{COO}$ in actual consumer decision making.

In conclusion, $\mathrm{COO}$ remains an important component of consumer decision making but the antecedent factors underpinning it, and the relationships between these factors, are much more complex than the prevailing theory suggests and this has important implications for both practitioners and academics. Indeed, the antecedent (and mediating) factors underpinning $\mathrm{COO}$ appear to provide good potential for further research, perhaps in different countries and in respect of different products to those used in this study, and for both national governments and commercial organisation's to fund such research activity. 


\section{$\underline{\text { References }}$}

Agarwal, S. and Sikri, S. (1996). "Country image: Consumer evaluation of product category extension", International Marketing Review, 13 (4): 23-29.

Agarwal, J. and Kamakura, W.A. (1999). "Country of origin: A competitive advantage", International Journal of Research in Marketing, 16 (4): 255-267.

Agbonifoh, B.A. and Elimimian, J.U. (1999). "Attitudes of developing countries towards "country-oforigin' products in an era of multiple brands", Journal of International Consumer Marketing, 11 (4), 97116.

Ahmed, S.A. and d'Astous, A. (1993). "L'influence dy pays d'origine sur l'evaluation de produit suscitant differents niveaux d'implication", Canadian Journal of Administrative Sciences, 10 (1): 48-59.

Ahmed, S.A. and d'Astous, A. (1996). "Country-of-origin and brand effects: a multi-dimensional and multi-attribute study", Journal of International Consumer Marketing, 9 (2): 93-115.

Ahmed, S.A. and d'Astous, A. (2001). "Canadian consumer perceptions of products made in newly industrializing East Asian countries", International Journal of Commerce and Management, 11 (1): 5481.

Ahmed, S.A. and d'Astous, A. (2008). "Antecedents, moderators and dimensions of country-of-origin evaluations”, International Marketing Review, 25 (1): 75-106.

Ahmed, S.A., d'Astous, A. and Eljabri, J. (2002a). "Impact of technological complexity on consumers' perceptions of products made in highly and newly industrializing countries", International Marketing Review, 19 (4/5): 387-407.

Ahmed, Z.U., Johnson, J.P., Ling, C.P., Fang, T.W. and Hui, A.K. (2002b). "Country-of-origin and brand effects on consumers' evaluations of cruise liners", International Marketing Review, 19 (3): 279-302.

Aichner, T., Forza, C., and Trentin, A, (2017). "The country-of-origin lie: Impact of foreign branding on customers' willingness to buy and willingness to pay when the product's actual origin is disclosed". International Review of Retail Distribution \& Consumer Research, 27 (1), 43-60.

Al-Aali, A., Randheer, K., and Hasin, S. (2015). "Do the subcomponents of country of origin trigger purchase intentions?". International Journal of Commerce \& Management, 25 (4), 627-640.

Andehn, M., Nordin, F., and Nilsson, M.E. (2016). "Facets of country image and brand equity: Revisiting the role of product categories in country-of-origin effect research". Journal of Consumer Behaviour, 15 (3), 225-238.

Andehn, M. and L'espoir Decosta, J.-N.P. (2018). "Re-imagining the country-of-origin effect: A promulgation approach". Journal of Product \& Brand Management, 27 (7), 884-896.

Arora, A.S., Mclntyre, J.R., Wu, J., and Arora, A. (2015). "Consumer response to diffusion brands and luxury brands: The role of country of origin and country of manufacture". Journal of International Consumer Marketing, 27 (3), 3-26.

Balabanis, G. and Diamantopoulos, A. (2004). "Domestic country bias, country of origin effect, and consumer ethnocentrism", Journal of the Academy of Marketing Science, 32 (1): 80-91.

Balabanis, G. and Diamantopoulos, A. (2008). "Brand origin identification by consumers: A classification perspective", Journal of International Marketing, 16 (1): 39-71.

Balabanis, G. and Diamantopoulos, A. (2011). "Gains and losses from the misperception of brand origin: The role of brand strength and country-of-origin image", Journal of International Marketing, 19 (2): 95116. 
Balabanis, G., Diamantopoulos, A., Mueller, R.D. and Melewar, T.C. (2001). "The impact of nationalism, patriotism and internationalism on consumer ethnocentric tendencies", Journal of International Business Studies, 32 (1): 157-175.

Balabanis, G., Mueller, R.D., and Melewar, T.C. (2002). "The human values' lenses of country of origin images", International Marketing Review, 19 (6): 582-610.

Balestrini, P. and Gamble, P. (2006). "Country-of-origin effects on Chinese wine consumers", British Food Journal, 108 (5): 396-412.

Beverland, M. and Lindgreen, A. (2002). "Using country-of-origin in strategy: the importance of context and strategic action", Brand Management, 10 (2): 147-167.

Bilkey, W.J. and Nes, E. (1982). "Country-of-origin effects on product evaluations", Journal of International Business Studies, 13 (1): 89-99.

Biswas, K., Chowdhury, M.K.H., and Kabir, H. (2011). "Effects of price and country of origin on consumer product quality perceptions: an empirical study in Bangladesh", International Journal of Management, 28 (3): 659-674.

Bizumic, B. (2014). "Who coined the concept of ethnocentrism? A brief report", Journal of Social and Political Psychology, 2 (1): 3-10.

Bloemer, J., Brijs, K. and Kasper, H. (2009). "The CoO-ELM model: A theoretical framework for the cognitive processes underlying country of origin-effects", European Journal of Marketing, 43 (1-2): 6289.

Bredahl, L. (2004). "Cue utilisation and quality perception with regard to branded beef", Food Quality and Preference, 15 (1): 65-75.

Chaiken, S. (1987). "The heuristic model of persuasion", in M.P. Zanna, J.M. Olson and C.P. Herman (eds), Social Influence: The Ontario Symposium, Erlbaum, Hillsdale, NJ, 3-39.

Chattalas, M. and Takada, H. (2013). "Warm versus competent countries: national stereotyping effects on expectations of hedonic versus utilitarian product properties", Place Branding \& Public Diplomacy, 9 (2): 88-97.

Cheah, I. Zainol, Z., and Phau, I. (2016). "Conceptualizing country-of-ingredient authenticity of luxury brands". Journal of Business Research, 69 (12), 5819-5826.

Chinen, K., Jun, M. and Hampton, G.M. (2000). "Product quality, market presence, and buying behavior: Aggregate images of foreign products in the US", Multinational Business Review, 8 (1): 29-38.

Chiou, J. (2003). "The impact of country of origin on pretrial and posttrial product evaluations: the moderating effect of consumer expertise", Psychology and Marketing, 20 (10): 935-954.

d'Astous, A. and Ahmed, S.A. (1999). "The importance of country images in the formation of consumer product perceptions", International Marketing Review, 16 (2): 108-125.

Dekhili, S. and Achabou, M.A. (2015). "The influence of the country-of-origin ecological image on ecolabelled product evaluation: An experimental approach to the case of the European ecolabel". Journal of Business Ethics, 131 (1), 89-106.

Diamantopoulos, A., Florack, A., Halkias, G., and Palcu, J. (2017). "Explicit versus implicit country stereotypes as predictors of product preferences: Insights from the stereotype content model". Journal of International Business Studies, 40 (8), 1023-1036.

Dichter, E. (1962). “The world customer”, Harvard Business Review, 4 (4), 113-122.

Dobrenova, F.V., Grabner-Krauter, S. and Terlutter, R. (2015). "Country-of-origin (COO) effects in the 
promotion of functional ingredients and functional foods". European Management Journal, 33 (5), 314321.

Dobrucali, B. (2019). "Country-of-origin effects on industrial purchase decision making: A systematic review of research". Journal of Business \& Industrial Marketing, 34 (2), 401-411.

Dodds, W.B. (1991). "In search of value: how price and store name information influence buyers' product perceptions", Journal of Services Marketing, 5 (3): 27-36.

Erickson, G.M., Johansson, J.K. and Chao, P. (1984). "Image variables in multi-attribute product evaluations: Country-of-origin effects", The Journal of Consumer Research, 11 (2), 694-699.

Ettenson, R., Wagner, J. Gaeth, G. (1988). "Evaluating the effect of country of origin and the 'Made in the USA' campaign: A conjoint approach", Journal of Retailing, 64 (1): 10-11.

Ferguson, J.L., Dadzie, K.Q. and Johnson, W.J. (2008). "Country-of-origin effects in service evaluation in emerging markets: some insights from five West African countries", Journal of Business \& Industrial Marketing, 23 (6): 429-437.

Fischer, P.M. and Zeugner-Roth, K.P. (2017). "Disentangling country-of-origin effects: the interplay of product ethnicity, national identity, and consumer ethnocentrism." Marketing Letters, 28 (2), 189-204.

Genc, E. and Wang, S.-C. (2017). "Is publishing country-of-design information beneficial for MNCs?". Journal of International Consumer Marketing, 29 (5), 278-292.

Godey, B.; Pederzoli, D.; Aiello, G.; Donvito, R.; Chan, P.; Oh, H.; Singh, R.; Skorobogatykh, I.I.; Tsuchiya, J.; and Weitz, B. (2012). "Brand and country-of-origin effect on consumers' decision to purchase luxury products", Journal of Business Research, (65) 10, 1461-1470.

Greenwald, A.G. and Banaji, M.R. (1995). "Implicit social cognition: attitudes, self-esteem, and stereotypes", Psychological Review, 102 (1): 4-27.

Guilhoto, L. de F. M. (2018). "The effects of country-of-origin on the service sector: A multidimensional approach". Resources and Entrepreneurial Development, 19 (1). Available online at: http://content.ebscohost.com/ContentServer.asp?EbscoContent=dGJyMNLr40SeprU4y9f3OLCmr1Ge prJSsay4TbeWxWXS\&ContentCustomer=dGJyMPGrtU6wrrNKuePfgeyx9Yvf5ucA\&T=P\&P=AN\&S=R $\& \mathrm{D}=\mathrm{bth} \& \mathrm{~K}=131239070$ Accessed on $7^{\text {th }}$ May 2019.

Gurhan-Canli, Z. and Maheswaran, D. (2000). "Cultural variations in country of origin effects", Journal of Marketing Research, 37 (3): 309-317.

Hamin and Elliott, G. (2006). "A less-developed country perspective of consumer ethnocentrism and 'country of origin' effects: Indonesian evidence", Asia Pacific Journal of Marketing and Logistics, 18 (2): 79-92.

Hamzaoui-Essoussi, L., Merunka, D. and Bartikowski, B. (2011). "Brand origin and country of manufacture influences on brand equity and the moderating role of brand typicality", Journal of Business Research, 64 (9): 973-978.

Han, C.M. (1989). "Country image: halo or summary construct?", Journal of Marketing Research, 26 (2): 222-229.

Han, C.M. and Terpstra, V. (1988). "Country of origin effects for uni-national and bi-national products", Journal of International Business Studies, 19 (3): 235-255.

Han, H-T. (2010). "The investigation of country-of-origin effect - using Taiwanese consumers' perceptions of luxury handbags as example", The Journal of American Academy of Business, 15 (2): 66-72.

Hanzaee, K.H. (2008). "The effect of country-of-origin (COO) on Iranian consumers' evaluations of 
foreign products in an Islamic country", The Business Review, 11 (2): 218-225.

Herz, M. and Diamantopoulos, A. (2017). "I use it but will tell you that I don't: Consumers' Country-ofOrigin cue usage denial”. Journal of International Marketing, 25 (2), 52-71.

Hofstede, G. (2001), "Culture's consequences: comparing values, behaviors, institutions, and organizations across nations", $2^{\text {nd }}$ edition, Thousand Oaks, California: SAGE.

Holdershaw, J. and Konopka, R. (2018). "Consumer knowledge of country of origin of fresh food at point of purchase". Journal of Promotion Management, 24 (3), 349-362.

Hsieh, M.H. (2004). "An investigation of Country-of-Origin effect using correspondence analysis: A cross-national context”, International Journal of Marketing Research, 46 (3): 267-295.

Huddlestone, P., Good, L.K. and Stoel, L. (2001). "Consumer ethnocentrism, product necessity and Polish consumers' perceptions of quality", International Journal of Retail \& Distribution Management, 29 (5): 236-246.

Hussein, M. and Fraser, I.F. (2018). "Hedonic analysis of consumers' valuation of country-of-origin of meat in the United Kingdom". Journal of Agricultural Economics, 69 (1), 182-198.

Insch, A. and Cuthbert, R. (2018). "Why country of origin still matters in food retailing: Implications for promotion management research". Journal of Promotion Management, 24 (3), 363-375.

Insch, A., Williams, S., and Knight, J.G. (2016). "Managerial perceptions of country-of-origin: An empirical study of New Zealand food manufacturers". Journal of Food Products Marketing, 22 (3), 304319.

Insch, G.S. (2003). "The impact of country-of-origin effects on industrial buyers' perceptions of product quality", Management International Review, 43 (3): 291-310.

Jaffe, E.D. and Martinez, C.R. (1995). "Mexican consumer attitudes towards domestic and foreign made products", Journal of International Consumer Marketing, 7 (3): 7-26.

Jap, W. (2010). "Confucius face culture on Chinese consumer consumption values toward global brands", The Journal of International Management Studies, 5 (1): 183-192.

Jian, W.U. and Guoqun, F.U. (2007). "The effects of brand origin country and made-in country on consumers' product evaluations and purchase intention", Frontiers of Business Research in China, 1 (3): $333-350$.

Jiménez, N. and Martin, S.S. (2012). "Emerging markets commerce: the role of country-of-origin and animosity in purchase intention", International Journal of Business \& Management, 7 (17): 34-42.

Jiménez, N. and Martin, S.S. (2014). "The mediation of trust in country-of-origin effects across countries", Cross Cultural Management, 21 (2): 15-171.

Johansson, J.K. (1989). "Determinants and effects of the use of 'made-in' labels", International Marketing Review, 6 (6): 47-58.

Johansson, J.K. and Thorelli, H.B. (1985). "International product positioning", Journal of International Business Studies, 16 (3): 57-75.

Johansson, J.K., Douglas, S.P. and Noanka, I. (1985). "Assessing the impact of country of origin on product evaluation: a new methodological perspective", Journal of Marketing Research, 22 (4), 388396.

Johnson, Z.S., Tian, Y., and Lee, S. (2016). "Country-of-origin fit: When does a discrepancy between brand origin and country of manufacture reduce consumers' product evaluations?". Journal of Brand Management, 23 (4), 403-418. 
Joji, A.N. and Ajin, M.A. (2015). "The role of consumer knowledge dimensions on country of origin effects: An enquiry of fast-consuming product in India". Vision, 19 (1), 1-12.

Josiassen, A., Lukas, B.A. and Whitwell, G.J. (2008). "Country-of-origin contingencies: competing perspectives on product familiarity and product development", International Marketing Review, 25 (4): 423-440.

Josiassen, A. and Assaf, A. (2010). "Country-of-origin contingencies: their joint influence on consumer behaviour", Asia Pacific Journal of Marketing and Logistics, 22 (3): 294-313.

Kabadayi, S. and Lerman, D. (2011). "Made in China but sold at FAO Schwarz: country-of-origin effect and trusting beliefs", International Marketing Review, 28 (1): 102-126.

Kardes, F.R., Cronley, M.L., Kellaris, J.J. and Posavac, S.S. (2004). "The role of selective information processing in price-quality inference", Journal of Consumer Research, 31 (2): 368-374.

Kaynak, E., Kucukemiroglu, O. and Hyder, A.S. (2000). "Consumers' country-of-origin (COO) perceptions of imported products in a homogenous less-developed country", European Journal of Marketing, 34 (9/10): 221-241.

Keller, K.L. (2003), "Brand synthesis: the multidimensionality of brand knowledge", Journal of Consumer Research, 29 (4): 595-600.

Kim, M.-Y. and Park, B.I. (2017). "The impact of country of origin on context effects in choice". International Marketing Review, 34 (6), 706-734.

Kim, S. and Pysarchik, D.T. (2000). "Predicting purchase intentions for uni-national and bi-national products", International Journal of Retail \& Distribution Management, 28 (6): 280-291.

Kim, S.J., Choi, Y.K., Kim, K.H., and Liu, H. (2015). "Country of origin and brand image influences on perceptions of online game quality". Journal of Consumer Behaviour, 14 (6), 389-398.

Kim, Y. (2006). "Do South Korean companies need to obscure their country-of-origin image?", Corporate Communications: An International Journal, 11 (2): 126-137.

Knight, G.A. and Calantone, R.J. (2000). "A flexible model of consumer country-of-origin perceptions: a cross-cultural investigation", International Marketing Review, 17 (2): 114-126.

Koschate-Fischer, N., Diamantopoulos, A. and Oldenkotte, K. (2012). "Are consumers really willing to pay more for a favourable country image? A study of country-of-origin effects on willingness to pay", Journal of International Marketing, 20 (1): 19-41.

Koubaa, Y. (2008). "Country of origin, brand image perception, and brand image structure", Asia Pacific Journal of Marketing and Logistics, 20 (2): 139-155.

Krupka, Z., Ozretic-Dosen, D. and Previsic, J. (2014). "Impact of perceived brand name origin on fashion brand's perceived luxury", Acta Polytechnica Hungarica, 11 (3): 153-166.

Kucukemiroglu, O., Kara, A. and Harcar, T. (2005). "Exploring buyer life-style dimensions and ethnocentrism among Canadian consumers: an empirical study", The Business Review, 4 (1): 210-217.

Laroche, M., Papadopoulos, N., Heslop, L. and Mourali, M. (2005). "The influence of country image structure on consumer evaluations of foreign products", International Marketing Review, 22 (1): 96-116.

LaTour, M.S. and Henthorne, T.L. (1990). "The PRC: An empirical analysis of country of origin product perceptions", Journal of International Consumer Marketing, 2 (4): 7-36.

Lee, D. and Ganesh, G. (1999). "Effects of partitioned country image in the context of brand image and familiarity: A categorization theory perspective", International Marketing Review, 16 (1): 18-39. 
Leonidou, L.C., Hadjimarcou, J., Kaleka, A. and Stamenoua, G.T. (1999). "Bulgarian consumers' perceptions of products made in Asia Pacific", International Marketing Review, 16 (2): 126-142.

Liefeld, J.P. (1993). "Experiments on country-of-origin effects: Review and meta-analysis of effect size", in N. Papadopoulos and L.A. Heslop (eds), Product - Country Images: Importance and Role in International Marketing, New York, NY: International Business Press, 117-156.

Liefeld, J.P. (2004). "Consumer knowledge and use of country-of-origin information at the point of purchase", Journal of Consumer Behaviour, 4 (2): 85-96.

Liefeld, J.P., Heslop, L.A., Papadopoulos, N., and Wall, M. (1996). "Dutch consumer use of intrinsic, country-of-origin, and price cues in product evaluation and choice", Journal of Consumer Marketing, 9 (1): $57-81$.

Lim, J.S. and Darley, W.K. (1997). "An assessment of demand artefacts in country-of-origin studies using three alternative approaches", International Marketing Review, 14 (4-5): 201-218.

Lim, J.S., Darley, W.K. and Summers, J.O. (1994). "An assessment of country of origin effects under alternative presentation formats", Journal of the Academy of Marketing Science, 22 (3): 274-283.

Lim, K.H., Hu, W., Maynard, L.J. and Goddard, E. (2014). "A taste for safer beef? How much does consumers' perceived risk influence willingness to pay for country-of-origin labelled beef", Agribusiness, 30 (1): $17-30$.

Lin, L-Y. and Chen, C-S. (2006). "The influence of the country-of-origin image, product knowledge and product involvement on consumer purchase decisions: an empirical study of insurance and catering services in Taiwan”, Journal of Consumer Marketing, 23 (5): 248-265.

Magnusson, P., Westjohn, S.A. and Zdravkovic, S. (2011). "What? I thought Samsung was Japanese': accurate or not, perceived country of origin matters", International Marketing Review, 28 (5): 454-472.

Maier, E. and Wilken, R. (2017). "Broad and narrow country-of-origin effects and the domestic country bias". Journal of Global Marketing, 30 (4), 256-274.

Martin, O.M. and Cervino, J. (2011). "Towards an integrative framework of brand country of origin recognition and determinants: a cross-classified hierarchical model", International Marketing Review, 28 (6): 530-558.

Maurya, H. and Gupta, D.D. (2015). "Exploration of country of origin effect in services: A literature driven approach". Marketing Review, 15 (3), 311-334.

Michaelis, M., Woisetschlager, D.M., Backhaus, C. and Ahlert, D. (2008). "The effects of country of origin and corporate reputation on initial trust: an experimental evaluation of the perception of Polish consumers", International Marketing Review, 25 (4): 404-422.

Nagashama, A.A. (1970). "A comparison of Japanese and US attitudes toward foreign products", The Journal of Marketing, 34 (1): 68-74.

Nagashama, A.A. (1977). "A comparative 'made-in' product image survey among Japanese businessmen", The Journal of Marketing, 41 (3): 95-100.

Nagy, S. (2019). "The impact of country of origin in mobile phone choice of generation $Y$ and Z". Journal of Management and Training for Industries, 4 (2), 16-29.

Okechuku, C. and Onyemah, V. (1966). "Nigerian consumer attitudes towards foreign and domestic products", Journal of International Business Studies, 30 (3): 611-622.

Omohundro, J.T. (2008). Thinking Like An Anthropologist: A Practical Introduction to Cultural Anthropology. Boston: McGraw Hill. 
Otter, V., Prechtel, B., and Theuvsen, L. (2018). "Country of origin effect for food products from developing and transition countries: A PLS analysis of German consumers' perceptions". Journal of International Food \& Agribusiness Marketing, 30 (4), 355-381.

Oxford University Press (2019), "English Oxford Living Dictionaries", Available online at: https://en.oxforddictionaries.com/definition/provenance Accessed: $13^{\text {th }}$ March 2019

Paswan, A.K. and Sharma, D. (2004). "Brand-country of origin (COO) knowledge and COO image: investigation in an emerging franchise market", Journal of Product \& Brand Management, 13 (3): 144155.

Peterson, R.A. and Jolibert, A.J.P. (1995). "A meta-analysis of country-of-origin effects", Journal of International Business Studies, 26 (4): 83-101.

Pham, K.C.V. (2006). "Strategic off-shoring from a decomposed COO's perspective: a cross-regional study of four product categories", Journal of American Academy of Business, 8 (2): 59-67.

Pharr, J.M. (2005). "Synthesizing country-of-origin research from the last decade: is the concept still salient in an era of global brands?" Journal of Marketing Theory and Practice, 13 (4): 34-45.

Phau, I. and Suntornnond, V. (2006). "Dimensions of consumer knowledge and its impacts on country of origin effects among Australian consumers: a case of fast-consuming product", Journal of Consumer Marketing, 23 (1): 34-42.

Piron, F. (2000). "Consumers' perceptions of the country-of-origin effect on purchasing intention of inconspicuous products", Journal of Consumer Marketing, 17 (4): 308-321.

Porto, R.B. and Soyer, T. da S. (2018). "Is naming brands in English worth doing? Effects of foreigness and country of origin on brand equity". Brazilian Business Review (English Edition), 15 (6), 606-623.

Prendergast, G.P., Tsang, S.L. and Chan, C.N.W. (2010). "The interactive influence of country of origin of brand and product involvement on purchase intention", Journal of Consumer Marketing, 27 (2): 180188.

Priyadarsini, K.J. and Goodwin, D.R. (2009). "Brand evaluation and purchase intention: The impact of $\mathrm{COO}$ of luxury cars and Indian metro customers", The IUP Journal of Brand Management, 6 (3\&4): 86103.

Rashid, A., Barnes, L., and Warnaby, G. (2016). "Management perspectives on country of origin". Journal of Fashion Marketing \& Management, 20 (2), 230-244.

Rashid, M.S. (2017). "Weakening the effect of unfavorable country of origin: A process-and-parameterassociated theoretical framework". Journal of Global Marketing, 30 (2), 87-98.

Reichert, M.J. and Altobelli, C.F. (2016). Country-of-origin effects in industrial goods markets: Do country-of-origin image effects differ for different buying center members?". Journal of Business Market Management, 9 (2), 623-649.

Reierson, C. (1966). "Are foreign products seen as national stereotypes?”, Journal of Retailing, 42 (3): 33-40.

Richardson, Jr. C.W. (2012). "Consumer demographics as antecedents in the animosity model of foreign product purchase", Special Issue of the International Journal of Business and Social Science, 3 (4): 13-21.

Roth, M.S. and Romeo, J.B. (1992). "Matching product category and country image perceptions: A framework for managing country-of-origin effects", Journal of International Business Studies, 23 (2): 477-497. 
Saeed, S. (1994). "Consumer evaluation of products in a global market", Journal of International Business Studies, 25 (3): 579-604.

Samiee, S., Shimp, T. and Sharma, S. (2005). "Brand origin recognition accuracy: Its antecedents and consumers' cognitive limitations", Journal of International Business Studies, 36 (4): 379-398.

Samiee, S. (2010). "Advancing the country image construct - a commentary essay", Journal of Business Research, 63 (4): 442-445.

Schatzle. S. and Jacob, F. (2019). "Stereotypical supplier evaluation criteria as inferred from countryof-origin information". Industrial Marketing Management, 78, 250-262.

Schooler, R.D. (1965). "Product bias in the central American common market", Journal of Marketing Research, 2 (4): 394-397.

Seetharaman P.B. (2004). "Modeling multiple sources of state dependence in random utility models: A distributed lag approach", Marketing Science, 23 (2), 263-271.

Sharma, P. (2011). "Country of origin effects in developed and emerging markets: exploring the contrasting roles of materialism and value consciousness", Journal of International Business Studies, 42 (2): 285-306.

Sharma, S., Shimp, T.A. and Shin, J. (1995). "Consumer ethnocentrism: A test of antecedents and moderators", Journal of the Academy of Marketing Science, 23 (1): 26-37.

Shimp, T.A. and Sharma, S. (1987). "Consumer ethnocentrism: Construction and validation of the CETSCALE", Journal of Marketing Research, 24 (3): 280-289.

Shimp, T.A., Samiee, S. and Madden, T.J. (1993). "Countries and their products: A cognitive structure perspective", Journal of the Academy of Marketing Science, 21 (4): 323-330.

Silverman, D., (2015). Interpreting Qualitative Data. $5^{\text {th }}$ edition, London: Sage.

Smaoui, F., Kilani, F.A., and Touzani, M. (2016). "Country-of-origin versus brand: Consumers' dilemma when choosing between generic and branded drugs in emerging countries". Journal of Product \& Brand Management, 25 (2), 148-159.

Solomon, M. (2015). Consumer Behaviour: Buying, Having, and Being. 11 $1^{\text {th }}$ global edition, Harlow, Essex: Pearson Education Ltd.

Steenkamp, J.E.M. (2019). "Global Versus Local Consumer Culture: Theory, Measurement, and Future Research Directions", Journal of International Marketing, 27 (1), 1-19.

Suh, Y., Hur, J.Y., and Davies, G. (2016). "Cultural appropriation and the country of origin effect". Journal of Business Research, 69 (8), 2721-2730.

Tigli, M., Pirtini, S. and Erdem, Y.C. (2010). "The perceived country of origin images in Turkey". International Business \& Economics Research Journal, 9 (8): 127-133.

Tiwari, R. (2016). "Comparing global brand and country of origin cues". Romanian Journal of Marketing, $4,56-60$.

Tse, D.K. and Gorn, G.J. (1993). "An experiment on the salience of country of origin in the era of global brands", Journal of International Marketing, 1 (1): 57-76.

Tseng, T-H. and Balabanis, G. (2011). "Explaining the product-specificity of country-of-origin effects", International Marketing Review, 28 (6): 581-600.

Usunier, J.-C. (1993). Marketing Across Cultures. Hemel-Hempstead: Prentice-Hall. 
Usunier, J.-C. (2006). "Relevance in business research: the case of country-of-origin research in marketing", European Management Review, 3 (1), 60-73.

Usunier, J.-C. and Cestre, G. (2007). "Product ethnicity: Revisiting the match between products and countries", Journal of International Marketing, 15 (3): 32-72.

Veale, R. and Quester, P. (2009). "Do consumer expectations match experience? Predicting the influence of price and country of origin perceptions of product quality", International Business Review, 18 (2), 134-144.

Verlegh, P.W.J. and Steenkamp, J.E.M. (1999). "A review and meta-analysis of country-of-origin research", Journal of Economic Psychology, 20 (5): 521-546.

Visbal, O., Ketty, H.-M., Orozco-Acosta, E., and Herzberg, M. (2017). "The influence of country of origin cues on product evaluation: Evidence from Swiss and German consumers". Journal of Technology Management \& Innovation, 12 (2), 18-25.

Wall, M., Liefeld, J. and Heslop, L.A. (1991). "Impact of country-of-origin cues on consumer judgments in multi-cue situations: A covariance analysis", Journal of the Academy of Marketing Science, 19 (2): $105-114$.

Walley, K., Custance, P., Feng, T., Yang, X., Li, C. and Turner, S. (2014). "The influence of country of origin on Chinese food consumers", Transnational Marketing Journal, 2 (2), 78-98. Available from: http://tplondon.com/journal/index.php/tmj/article/viewFile/386/328 Accessed: $7^{\text {th }}$ May 2019.

Wang, C-K. and Lamb, C.W. (1983). "The impact of selected environmental forces upon consumers' willingness to buy foreign products", Journal of the Academy of Marketing Science, 11 (1), 71-83.

Winit, W., Gregory, G., Cleveland, M. and Verlegh, P. (2014). "Global vs local brands: how home country bias and price differences impact brand evaluations", International Marketing Review, 31 (2): 102-128.

Wong, C.Y., Polonsky, M.J. and Garma, R. (2008). "The impact of consumer ethnocentrism and country of origin sub-components for high involvement products on young Chinese consumers' product assessments", Asia Pacific Journal of Marketing and Logistics, 20 (4): 455-478.

Wood W., Quinn J. and Kashy D. (2002). "Habits in everyday life: Thought, emotion, and action", Journal of Personality and Social Psychology, 83 (6), 1281-1297.

World Bank (2017). Gross Domestic Product 2017. Available online at: https://databank.worldbank.org/data/download/GDP.pdf Accessed: $7^{\text {th }}$ May 2019.

Wu, L., Ju, I., and Dodoo, N.A. (2016). "Understanding the impact of matchup between country-of-origin facets and country stereotypes on advertising effectiveness", Journal of Global Marketing, 29 (4), 203217.

$\mathrm{Xu}, \mathrm{H}$., Leung, A. and Yan, R-N. (2013). "It is nice to be important, but it is more important to be nice: country-of-origin's perceived warmth in product failures", Journal of Consumer Behaviour, 12 (4): 285292.

Zain, O.M. and Yasin, N.M. (1997). "The importance of country-of-origin information and perceived product quality in Uzbekistan", International Journal of Retail \& Distribution Management, 25 (4): 138145.

Zhang, Y. (1996). "Chinese consumers' evaluation of foreign products: The influence of culture, product types and product presentation format", European Journal of Marketing, 30 (12): 50-69.

Zhao, X., Zhao, K., and Deng, J. (2019). "Geography still matters: Examine the role of location in online markets for foreign branded products”. Decision Sciences, 50 (2), 285-310. 
Zolfagharian, M.A. and Sun, Q. (2010). "Country of origin, ethnocentrism and bicultural consumers: the case of Mexican Americans", Journal of Consumer Marketing, 27 (4): 345-357.

Zolfagharian, M.A., Saldivar, R. and Sun, Q. (2014). "Ethnocentrism and country of origin effects among immigrant consumers", Journal of Consumer Marketing, 31 (1): 68-84. 